\title{
Mucous FOXP3+ Treg cells and Interleukin-23 expression in the intestinal mucosa of children with ulcerative colitis
}

\section{Ülseratif kolitli çocukların intestinal mukozasında FOXP3+ Treg hücreleri ve İnterlökin-23 ekspresyonu}

\begin{abstract}
Ulas Emre Akbulut ${ }^{1}$, Safak Ersoz ${ }^{2}$, Gokhan Tumgor ${ }^{3}$, Mehmet Agin $^{3}$, Fatih Unal ${ }^{4}$, Erhun Kasirga ${ }^{5}$, Murat Cakir $^{6}$
${ }^{1}$ Dept. of Pediatric Gastroenterology Hepatology and Nutrition, University of Health Sciences, Antalya Education and Research Hospital, Antalya, Turkey, ${ }^{2}$ Dept. of Pathology, Karadeniz Technical University, Faculty of Medicine, Trabzon, Turkey, ${ }^{3}$ Dept. of Pediatric Gastroenterology Hepatology and Nutrition, Cukurova University, Faculty of Medicine, Adana, Turkey, ${ }^{4}$ Dept. of Pediatric Gastroenterology Hepatology and Nutrition, Dortcelik Children Hospital, Bursa, Turkey, ${ }^{5}$ Dept. of Pediatric Gastroenterology Hepatology and Nutrition, Celal Bayar University, Faculty of Medicine, Manisa, Turkey, ${ }^{6}$ Dept. of Pediatric Gastroenterology Hepatology and Nutrition, Karadeniz Technical University, Faculty of Medicine, Trabzon, Turkey
\end{abstract}

\section{Abstract}

Background Ulcerative colitis (UC) is thought to result from an aberrant immune response. Forkhead box protien 3 (FOXP3) regulatory T (Treg) cells and Interleukin (IL)-23/T-helper 17 pathway play an important role in the pathogenesis of inflammatory bowel disease, but little is known about their role in children with UC.

Objective The aim of this study was to investigate the role of FOXP3 and IL-23 in the pathogenesis of UC by determining them in intestinal tissues of children with the disease.

Methods We studied 29 patients with UC (18 pancolitis, nine left-sided colitis, and two proctocolitis) and 11 control subjects. Immunohistochemistry was used to examine FOXP3+ Treg cells and IL-23 in intestinal biopsy specimens from UC patients and from non-inflamed tissues in the control group.

Results UC patients' FOXP3+ Treg cells rate were significantly higher than those of the control group (45.67 \pm 10.83 vs. $22.06 \pm 8.09, \mathrm{p}=0.007)$. IL-23 expression rate in patients with UC was significantly higher than those of the control subjects $(24.33 \pm 13.81$ vs. $12.91 \pm 5.06, \mathrm{p}=0.009)$. FOXP3 ${ }^{+}$Treg cells $(43.21 \pm 16.97)$ and IL-23 (25.12 \pm 14.92$)$ expression in patients with pancolitis were higher than in the control group ( $\mathrm{P}=0.012$ vs. $\mathrm{p}=0.022$ ). However, no differences were determined in FOXP3 $3^{+}$Treg cells and IL-23 in patients with left colon involvement and proctocolitis compared to the control group.

Conclusions FOXP3+ Treg cell and IL-23 expression were higher in the intestinal mucosa of children with UC. These data indicate that new therapeutic options directed toward inhibiting the IL23 pathway and raising Treg cell numbers may permit more efficacious treatment of UC.

Key words: Ulcerative colitis, children, interleukin-23, FOXP3, cytokine

\section{Özet}

Amaç Ülseratif kolitin (UK), anormal immün yanıt sonucu geliştiği düşünülmektedir. Forkhead box protien 3 (FOXP3) T regülatuvar (Treg) hücreleri ve interlökin (IL)-23/T-helper 17 yolağı, inflamatuvar bağırsak hastalığının patogenezinde önemli bir rol oynamaktadır. Ancak bu yolağın UK'li çocuklardaki rolü ile ilgili bilgilerimiz sınırlıdır.

Corresponding author: Ulas Emre Akbulut, Dept. of Pediatric Gastroenterology Hepatology and Nutrition, University of Health Sciences, Antalya Education and Research Hospital, Antalya, Turkey, Phone: +90 24224944 00, Fax: +90 242 249 44 87, E-mail: ulasemre@hotmail.com Received: 1 May 2018 Accepted: 18 June 2018 
Bu çalışmanın amacı UK'li çocukların bağırsak mukozasinda FOXP3 ve IL-23'ün düzeylerinin belirlenerek hastalığın patogenezindeki rollerinin araştırılmasıdır.

Yöntem Yirmi dokuz UK'li hasta (18 pankolit, dokuz sol kolon tutulumlu ve iki proktokolit) ve 11 kontrol hastası çalışmaya dahil edildi. İmmünohistokimyasal boyama yöntemi ile, UK hastaların inflamasyonlu dokularından ve kontrol hastalarının inflamasyon içermeyen dokularından alınan biyopsi örneklerinde FOXP3+ Treg hücreleri ve IL-23 düzeyleri incelendi.

Bulgular Ülseratif kolitli hastalarda FOXP3 ${ }^{+}$Treg hücre seviyesi kontrol grubuna göre önemli oranda yüksekti ( $45.67 \pm 10.83$ ve $22.06 \pm 8.09, p=0.007)$. IL-23 düzeyi de UK hastalarında kontrol grubuna göre anlamlı olarak yüksekti $(24.33 \pm 13.81$ vs. $12.91 \pm 5.06, \mathrm{p}=0.009)$. Pankolitli hastalarda FOXP3 ${ }^{+}$Treg hücreleri (43.21 \pm 16.97$)$ ve IL-23 ( $25.12 \pm 14.98)$ ekspresyonu kontrol grubundan daha yüksek olduğu görüldü ( $\mathrm{p}=0.012$ ve $\mathrm{p}=0.022$ ). Ancak, kontrol grubu ile sol kolon tutulumu ve proktokoliti olan hastalar arasında FOXP3 ${ }^{+}$Treg hücreleri ve IL-23 ekspresyonunda farklılık bulunmuyordu.

Sonuçlar Ülseratif kolitli çocukların bağırsak mukozalarinda FOXP3+ Treg hücreleri ve IL-23 ekspresyonu daha yüksek olduğu tespit edildi. Bu sonuçlar, IL-23 yolağını engellemeye ve Treg hücre sayılarını yükseltmeye yönelik yeni tedavi seçeneklerin, UK'in daha etkili bir şekilde tedavi edilmesine yardımcı olabileceğini göstermektedir.

Anahtar Kelimeler: Ülseratif kolit, çocuk, interlökin-23, FOXP3, sitokin

\section{Introduction}

Ulcerative colitis (UC) is a chronic condition characterized by diffuse inflammation in the colonic mucosa. ${ }^{1}$ Although the pathogenesis is uncertain, several studies have shown that the disease is multifactorial, involving both genetic and environmental components. ${ }^{2}$ There is also evidence that immune disequilibrium, such as excessive inflammatory response and decreased immunoregulatory cells, leads to the development of $\mathrm{UC}^{3}$

Immunological self-tolerance is established by regulatory $\mathrm{T}$ (Treg) cells, a subgroup of the $\mathrm{CD}^{+} \mathrm{T}$ cells that inhibit the development of other $\mathrm{T}$ cells and their functions. ${ }^{4,5}$ Forkhead box protien 3 (FOXP3) is a tran- scriptional regulator and a member of the forkhead and winged helix family, of critical importance to Treg cell formation and functions. ${ }^{6}$ Studies have shown that FOXP3 gene mutations can lead to autoimmune diseases such as immune dysregulation, polyendocrinopathy, enteropathy, and X-linked syndrome or X-linked autoimmune allergic dysregulation. ${ }^{7,8}$ In addition, studies have shown that imbalance between Treg and effector $\mathrm{T}$ cells play a key role in the pathogenesis of UC. ${ }^{9}$

Interleukin (IL)-23 is a crucial component in the maintenance of immune response. It performs this role by regulating $\mathrm{T}$ cell memory function and by affecting the proliferation and survival of T helper 17 (Th17) cells responsible for manufacturing IL-17. ${ }^{10,11}$ There is growing evidence that IL-23, a cytokine consisting of IL-12p40 and IL-23p19, is significantly involved in the development of several immune-mediated inflammatory conditions by recruiting various inflammatory cells and Thl7 cells. ${ }^{12}$ Available data from studies strongly support that, a role for the IL-23 in intestinal inflammation. ${ }^{13}$ Moreover, genome-wide association studies have also shown that IL-23 is associated with differentiation of Th17 cells and susceptibility to UC. ${ }^{14}$

Understanding the immunological mechanisms involved in inflammation in the intestinal mucosa will facilitate the discovery of specific markers capable of use in diagnosis of the disease and in the development of new drugs. Studies have shown that impairment of $\mathrm{FOXP}^{+}$Treg cells and IL-23 functions play a significant role in the development of UC. ${ }^{3}$ However, studies on this subject in children are limited. The purpose of this study was to investigate the role of FOXP3 and IL23 in the pathogenesis of UC by determining them in intestinal tissues of children with the disease.

\section{Materials and Methods}

\section{Study population}

Patients diagnosed with UC were included in the study. The study was performed in line with the principles of the Helsinki Declaration and after approval had been granted by the local ethical committee (Registry number: 2013/173 Identifier: Karadeniz Technical University, Fac- 
ulty of Medicine, Clinical Research Ethics Committee).

Patients' demographic data, site of involvement, perinuclear neutrophil antibodies (p-ANCA), therapy received and responses to treatment were recorded. Biopsies were taken from all colon segments and UC compatible active lesions were included in the study. A control group was established consisting of age and sex matched children undergoing colonoscopy for any reason and without any detected pathology.

\section{Immunohistochemical staining for FOXP3 and IL-23}

All tissue samples were formalin-fixed and paraffin-embedded. Slides stained with hematoxylin and eosin were assessed by a pathologist for confirmation of diagnosis. For immunohistochemical study, 4- $\mu$ m sections were prepared for FOXP3 antibody (Sc-53876, Santa Cruz Biotechnology), and IL-23 antibody (Sc-50303 Santa Cruz Biotechnology) from paraffin blocks of previously selected slides. Following deparaffinization, antigen retrieval was performed in EDTA buffer using a microwave oven. Next, 60-min incubation was performed with a primary antibody (dilution 1:100 for IL-23, 1:100 for anti-FOXP3), a biotinylated secondary antibody. A DAB kit was used as a chromogen for immunohistochemical study. Slides were counterstained with hematoxylin, dehydrated, cleared, and mounted. The percentage of immunostaining in lymphoid cells in the lamina propria was assessed by counting positive and negative cells using Analysis FIVE software (Olympus, Japan) and was expressed as the staining rate (\%).

\section{Statistical Analysis}

Data were analyzed on SPSS 13,0 (SPSS Inc., Chicago, IL) software. Descriptive statistics were expressed as mean \pm standard deviation (SD). The independent two-sample t test was used for two-group comparison of normally distributed variables, and the Mann-Whitney $\mathrm{U}$ test for non-normally distributed variables. The chi square test was used to compare categoric variables. Statistical significance was set at $\mathrm{p}<0.05$.

\section{Results}

Biopsy specimens taken from 45 patients at time of diag- nosis were studied. However, 16 patients were excluded due to insufficient staining, and 29 subjects were finally enrolled. The mean age of the children with UC included in the study was $14.24 \pm 3.08$ years ( 7 -18 years). Eighteen $(62.1 \%)$ patients were male and 11 (37.9\%) female. Pancolitis was present in 18 (62.1\%) patients, left colon involvement in 9 (31.0\%) and proctocolitis in 2 (6.9\%). P-ANCA was positive in 12 (41.3\%) patients. Steroid therapy was administered to 21 (72.4\%) patients, other patients were administered 5-aminosalicylic acid. Eighteen $(85.7 \%)$ of these patients responded to treatment, while no response was observed in 3 (14.3\%). Patients not responding to steroid treatment received TNF-alpha therapy (Table 1).

Table 1. Demographic and clinical features of children with UC

\begin{tabular}{lc}
\hline & UC patients (n=29) \\
Male, n (\%) & $18(62.1)$ \\
Age (years), mean \pm SD (range) & $14.24 \pm 3.08$ \\
Site of involvement, n (\%) & $18(62.1)$ \\
Pancolitis & $9(31.0)$ \\
Left sided colitis & $2(6.9)$ \\
Proctocolitis & $21(72.4)$ \\
p-ANCA positive, n (\%) & $18(85.7)$ \\
Steroid therapy administered, $\mathrm{n}(\%)$ & $3(14.3)$ \\
Response to steroid therapy, n (\%) & \\
Responsive & \\
Unresponsive &
\end{tabular}

UC: ulcerative colitis, $p$-ANCA: perinuclear neutrophil antibodies

\section{Expression of Foxp $3^{+}$Treg cells in colonic mucosa of UC patients}

UC patients' FOXP3+ Treg cells rate were significantly higher than those of the control group $(45.67 \pm 10.83$ vs. $22.06 \pm 8.09, \mathrm{p}=0.007$ ) (Fig. 1). No correlation was observed between age, sex, p-ANCA positivity or response to steroid therapy and FOXP3 ${ }^{+}$Treg cell expression in patients with UC ( $>>0.05)$. No difference was determined in FOXP3 ${ }^{+}$Treg cells in patients with left 


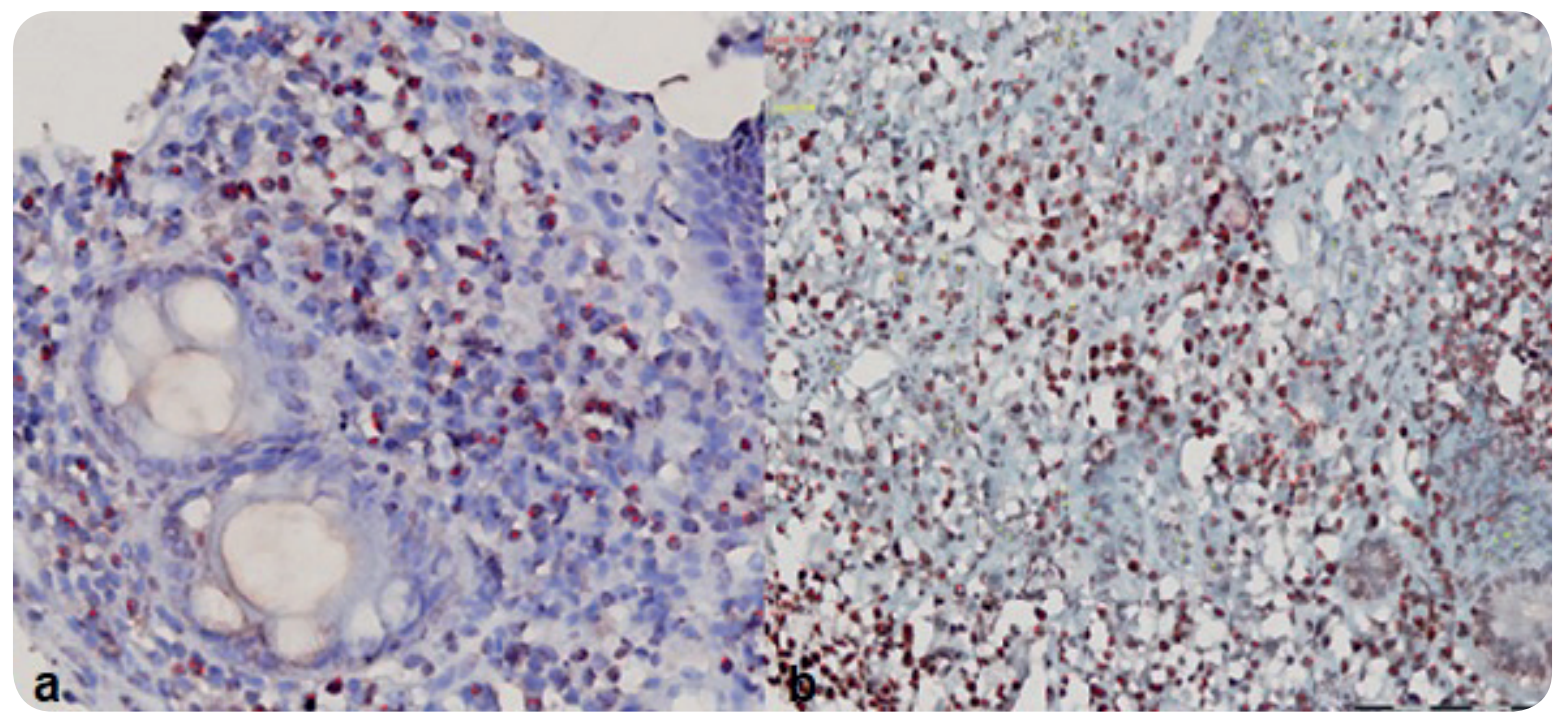

Fig. 1. FOXP3 ${ }^{+}$Treg cells in the lamina propria of a control subject (a) and a patient with ulcerative colitis (b). Slides stained with hematoxylin and eosin. Shown are representative histologic sections stained with FOXP3 antibody. (IHCx400 and 200).

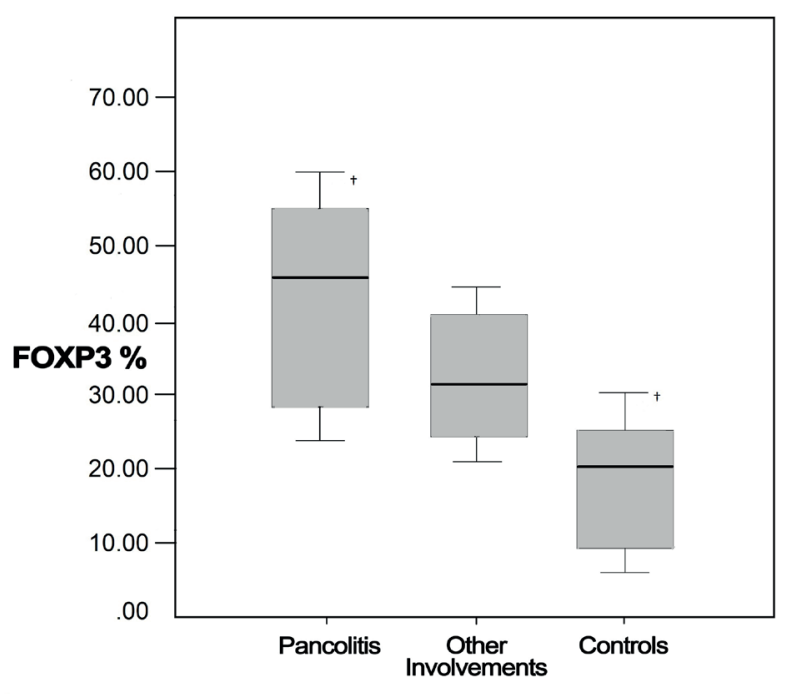

${ }^{\dagger} \mathrm{p}=0.012$

Fig. 2. Comparison of FOXP3 ${ }^{+}$Treg cells in terms of side of involvement

colon involvement and proctocolitis compared to the control group $(\mathrm{p}<0.05)$, although higher FOXP3 ${ }^{+}$Treg cells were observed in the patients with pancolitis compared to the control group ( $\mathrm{p}=0.012$ ) (Fig. 2).

\section{Expression of IL-23 protein in the colonic mucosa of UC patients}

IL-23 expression in patients with UC were significantly higher than those of the control subjects $(24.33 \pm 13.81$ vs. $12.91 \pm 5.06, \mathrm{p}<0.01)$. No correlation was deter-

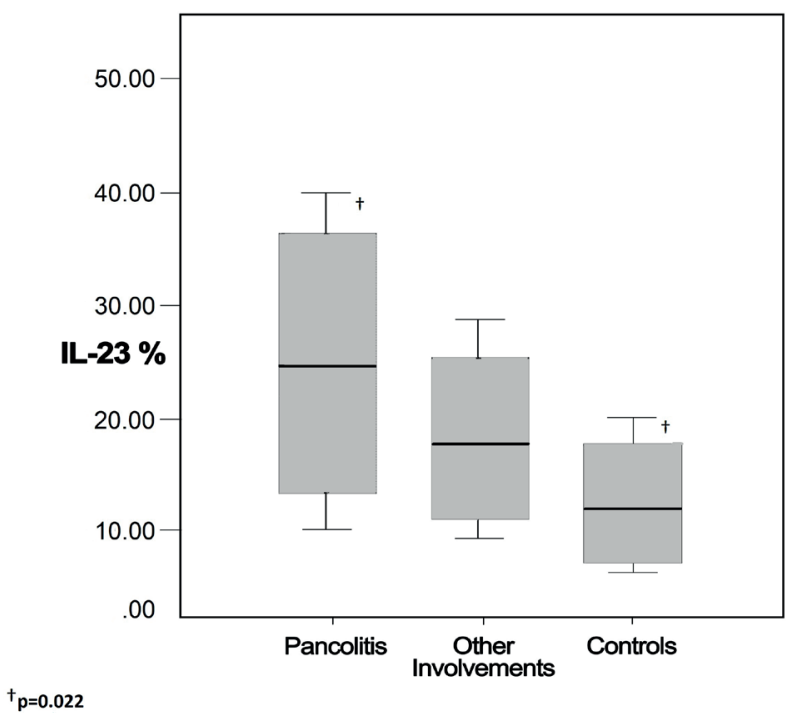

Fig. 3. Comparison of IL-23 in terms of side of involvement

mined between age, sex, p-ANCA positivity or response to steroid therapy and IL-23 expression in the subjects with UC ( $p>0.05)$. IL-23 expression rate in patients with pancolitis $(25.12 \pm 14.98)$ were higher than those in the control group ( $\mathrm{p}=0.022$ ) (Fig. 3-4). However, we observed no significant difference in IL-23 expression in patients with left colon involvement and proctocolitis compared to the healthy controls $(\mathrm{p}>0.05)$ 


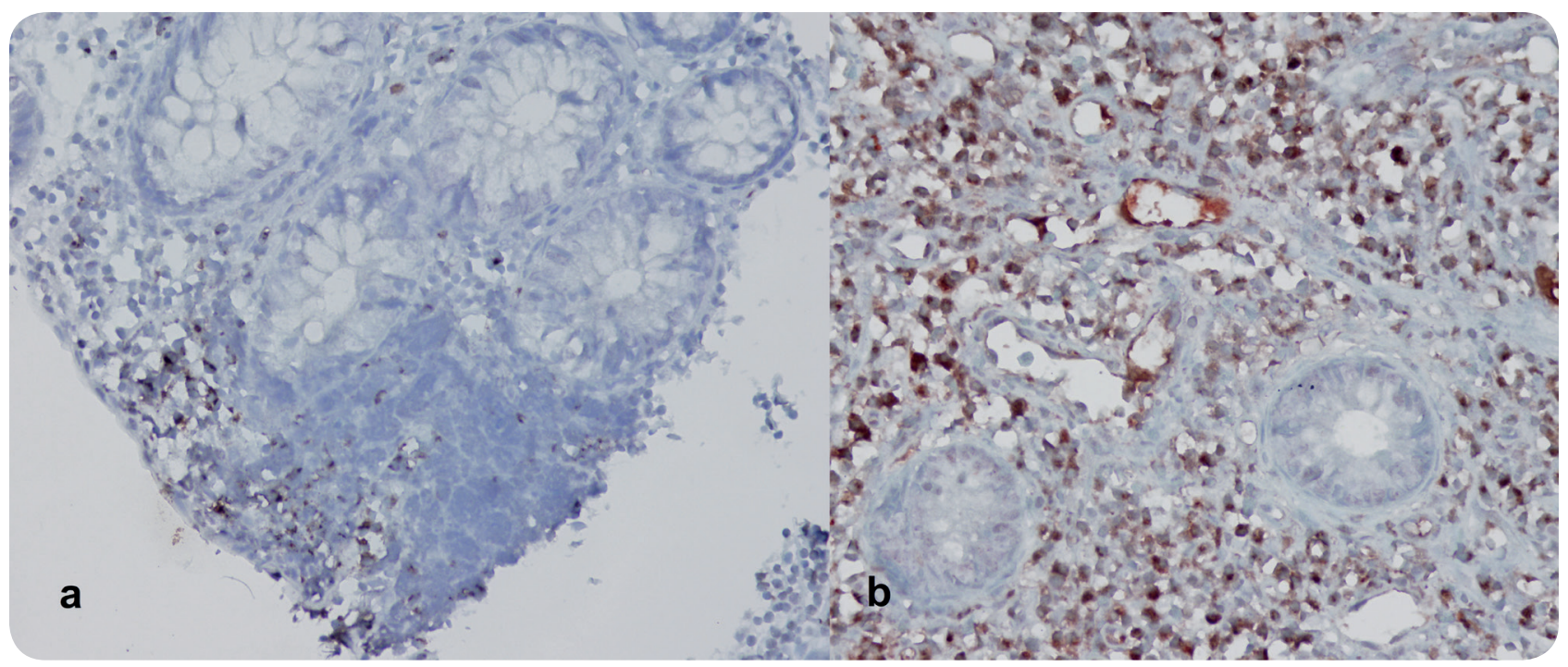

Fig. 4. IL-23 in the lamina propria of a control subject (a) and a patient with ulcerative colitis (b). Slides stained with hematoxylin and eosin. Shown are representative histologic sections stained with IL-23 antibody. (IHCx400).

\section{Discussion}

This study investigated FOXP3+ Treg cell and IL-23 expression in the colonic mucosa of children with UC. We observed a marked increase in FOXP3 ${ }^{+}$Treg cells and IL-23 in UC compared to normal, healthy mucosa.

The pathogenesis of UC is unclear. Nevertheless, the available evidence seems to indicate a network of inter-related genetic predisposition and environmental risk factors possibly resulting in uncontrolled intestinal immune response against the commensal microbial flora and in subsequent tissue damage. ${ }^{15}$ A fine equilibrium exists between Treg and effector $\mathrm{T}$ cell responses in the intestinal immune response. One of previous research has identified the function of Treg in patients with UC, and an imbalance between Treg and effector $\mathrm{T}$ cells has been demonstrated in the pathogenesis of UC. ${ }^{9}$ Recent research has also confirmed that IL-23 is strongly associated with this balance and is essential for the development of chronic intestinal inflammation. ${ }^{16}$ IL-23 has been shown to the main cytokine involved in intestinal inflammation in IBD in murine. Findings from human studies also strongly support a role for the IL-23 in IBD. ${ }^{17}$ The crucial role of the IL-23 pathway in the development of IBD was confirmed by the observation of association of several single nucleotide polymorphism (SNPs) throughout the IL23R gene with UC. ${ }^{14,18}$
The most important of these SNPs is a variant of IL23R responsible for encoding an amino acid change from arginine to glutamine at position 381, and which reduces risk of IBD. ${ }^{19}$ This protective variant results in a loss-offunction of IL23R, and decreased IL-17 production. ${ }^{20,21}$ Furthermore, higher expression of IL-23 have been observed in the inflamed mucosa of subjects with IBD. In children, increased IL-23 expression in UC has been recently shown by Rosen et al. ${ }^{22}$ Similarly, our findings showed IL-23 elevation with immunohistochemistry in the colonic mucosa of pediatric subjects with UC.

Clinical observational and experimental studies with animals have shown that Treg cells are critically important in preventing intestinal inflammation. ${ }^{23,24}$ This supports the idea that Treg cells play an important role in the pathogenesis of UC. Treg cells expression have been shown to decrease in both serum and in intestinal mucosa in graft versus host disease that develops after hematopoietic stem cell transplantation, and which resembles IBD in terms of intestinal inflammation pattern. ${ }^{25,26}$ However, in the first study in which Treg cells were isolated in the intestinal lamina propria of patients with IBD, the suppressor activities of these cells was shown to be no different to that in the control group. ${ }^{27}$ Subsequent studies determined an increase in FOXP3 ${ }^{+}$Treg cells in the intestinal mucosa of patients with IBD. ${ }^{23,28}$ In contrast to the elevated expression of FOXP3 ${ }^{+}$Treg 
cells in the intestinal mucosa, significantly high levels have not been determined in the blood of patients with UC. ${ }^{3}$ During the course of the disease, Treg cells in peripheral blood seek to establish homeostasis by migrating to the inflamed mucosa. Although the number of Treg cells in the inflamed mucosa increases, a decrease in cytokine production, impairment of the toll-like receptor pathway and insensitivity in $\mathrm{T}$ cell receptors have also been reported. ${ }^{29-31}$ These findings suggest a possible impairment of Treg cell inhibitory functions in patients with UC. FOXP3 expression in the present study were significantly higher in pediatric subjects with UC than in the control group.

As a result of studies in the early $21^{\text {st }}$ century, anti-TNFa drugs have been developed for use in the treatment of UC and other inflammatory diseases. ${ }^{32}$ However, only one in three patients receiving TNF-antagonist therapy remain in clinical remission after 1 year, and studies have also reported that TNF-antagonists can result in severe or even life-threatening events. ${ }^{33,34}$ Further therapeutic options are therefore now required. Some experimental animal studies have reported a decrease in intestinal inflammation with IL-17 blockage ${ }^{35}$, while others have observed an increase in inflammation. ${ }^{36}$ The latest studies have determined a decrease in intestinal epithelial barrier functions and in intestinal anti-microbial protein expression with IL-17 or IL-17R blockage in mice with colitis induced with dextran sodium sulfate (DSS). ${ }^{37,38}$ Due to the numerous targets of IL-17, the adverse effects of IL-17 blockage are many more than its contribution to the prevention of inflammation in the bowel. The IL17-independent results of targeting upstream in the IL23 pathway that have been observed are probably various. IL23 is capable of exacerbating the pathogenic behavior of non-Th17 and Th17 cell subsets, thus enhances intestinal inflammation. ${ }^{39}$ Decreased intestinal inflammation has been reported after the induction of colitis in IL-23 deficient mice or in those receiving neutralizing antibodies against IL23p19. ${ }^{40-42}$ In addition, studies have shown that several inflammatory diseases, including inflammatory bowel diseases, can be prevented and treated through the transfer of Treg cells. ${ }^{32}$ In one study involving IBD, Treg transfer was performed in 20 patients with Crohn's disease, and clinical improvement was determined in $40 \% .{ }^{43}$

In this study, we observed increased expression of FOXP3 ${ }^{+}$Treg cells and IL-23 in the intestinal mucosa of children with UC. Furthermore, persistence of inflammation despite an increase in Treg cell numbers in the intestinal mucosa of children with UC compared to healthy children indicates impairment occurring in the functions of these cells.

This study has some limitations. First, the study population was relatively small and most patients had pancolitis. Second, we characterized FOXP3 and IL-23 expression by immunohistochemistry in biopsies of UC patients. However, we were not perform isotype control stainings or blocking the signal with recombinant protein to better demonstrated the specifty. Third, due to limitations in our resources, we were not able to analyze mRNA levels to quantitated expression of FOXP3 and IL-23.

In conclusion, better understanding of IL-23 pathway and changes in Treg cell functions in UC may help improve our understanding of the pathogenesis of the disease and lead to the discovery of novel diagnostic markers. The drugs currently used in the treatment of UC have severe side-effects, such as development of infection and malignity, in the long term. We think that novel therapeutic options directed toward inhibiting the IL23 pathway and raising Treg cell numbers may permit both more efficacious treatment and also fewer undesirable side-effects.

\section{References}

1. Nikolaus S, Schreiber S. Diagnostics of inflammatory bowel disease. Gastroenterology 2007;133:1670-89.

2. Xavier RJ, Podolsky DK. Unravelling the pathogenesis of inflammatory bowel disease. Nature 2007;448:427-34.

3. Wang Y, Liu XP, Zhao ZB, et al. Expression of $\mathrm{CD}^{+}$ forkhead box P3 (FOXP3) ${ }^{+}$regulatory $\mathrm{T}$ cells in inflammatory bowel disease. J Dig Dis 2011;12:286-94.

4. Sakaguchi S, Sakaguchi N, Asano M, et al. Immunologic self-tolerance maintained by activated $\mathrm{T}$ cells expressing IL-2 receptor alpha-chains (CD25). 
Breakdown of a single mechanism of self-tolerance causes various autoimmune diseases. J Immunol 1995; 155:1151-64.

5. Mottet C, Uhlig HH, Powrie F. Cutting edge: cure of colitis by CD4(+) CD25(+) regulatory T cells. J Immunol 2003;170:3939-43.

6. Ziegler SF. FOXP3: of mice and men. Annu Rev Immunol 2006;24:209-26.

7. Bennett CL, Ochs HD. IPEX is a unique X-linked syndrome characterized by immune dysfunction, polyendocrinopathy, enteropathy, and a variety of autoimmune phenomena. Curr Opin Pediatr 2001;13:533-8.

8. Wildin RS, Ramsdell F, Peake J, et al. X-linked neonatal diabetes mellitus, enteropathy and endocrinopathy syndrome is the human equivalent of mouse scurfy. Nat Genet 2001;27:18-20.

9. Voskens CJ, Fischer A, Roessner S, et al. Characterization and expansion of autologous gmp-ready regulatory $\mathrm{T}$ cells for Treg-based cell therapy in patients with ucerative colitis. Inflamm Bowel Dis 2017;23:1348-59.

10. Park H, Li Z, Yang XO, et al. A distinct lineage of CD4 $T$ cells regulates tissue inflammatory by producing interleukin 17. Nat Immunol 2005;6:1133-41.

11. Harrington LE, Hatton RD, Mangan PR, et al. Interleukin 17-producing $\mathrm{CD}^{+}{ }^{+}$effector $\mathrm{T}$ cells develop via a lineage distinct from the $\mathrm{T}$ helper type 1 and 2 lineages. Nat Immunol 2005;6:1123-32.

12. Liu Z, Yadav $\mathrm{PK}, \mathrm{Xu} \mathrm{X}$, et al. The increased expression of IL-23 in inflammatory bowel disease promotes intraepithelial and lamina propria lymphocyte inflammatory responses and cytotoxicity. J Leukoc Biol 2011;89:597-606.

13. Yang J, Xu L. Elevated il-23r expression and fox$\mathrm{p}^{+}{ }^{+}$rorgt $^{+}$cells in intestinal mucosa during acute and chronic colitis. Med Sci Monit 2016;22:2785-92.

14. Duerr RH, Taylor KD, Brant SR, et al. A genome-wide association study identifies IL-23R as an inflammatory bowel disease gene. Science 2006;314:1461-3.

15. Abraham C, Cho JH. Inflammatory bowel disease. N. Engl J Med 2009;361:2066-78.

16. Izcue A, Hue S, Buonocore, et al. Interleukin-23 restrains regulatory $\mathrm{T}$ cell activity to drive $\mathrm{T}$ cell-dependent colitis. Immunity 2008;28:559-70.

17. Geremia A, Jewell DP. The IL-23/IL-17 pathway in inflammatory bowel disease. Expert Rev Gastroenterol Hepatol 2012;6:223-37.

18. McGovern D, Powrie F. The IL23 axis plays a key role in the pathogenesis of IBD. Gut 2007;56:1333-36.

19. Jostins L, Ripke S, Weersma RK, et al. Host-microbe interactions have shaped the genetic architecture of inflammatory bowel disease. Nature 2012;491:119-24.

20. Pidasheva S, Trifari S, Phillips A, et al. Functional studies on the IBD susceptibility gene IL23R implicate reduced receptor function in the protective genetic variant R381Q. PLoS One 2011;6:e25038.

21. Kim SW, Kim ES, Moon CM, et al. Genetic polymorphisms of IL-23R and IL-17A and novel insights into their associations with inflammatory bowel disease. Gut 2011;60:1527-36.

22. Rosen MJ, Karns R, Vallance JE, et al. Mucosal expression of type 2 and type 17 immune response genes distinguishes ulcerative colitis from colon-only crohn's disease in treatment-naive pediatric patients. Gastroenterology 2017;152:1345-57.

23. Uhlig HH, Coombes J, Mottet C, et al. Characterization of Foxp $3^{+} \mathrm{CD} 4+\mathrm{CD} 25+$ and IL-10-secreting CD4+CD25+ T cells during cure of colitis. J Immunol 2006; 177:5852-60.

24. Gad M. Regulatory T cells in experimental colitis. Curr Top Microbiol Immunol 2005;293:179-208.

25. Miura Y, Thoburn CJ, Bright EC, et al. Association of Foxp3 regulatory gene expression with graft-versushost disease. Blood 2004;104:2187-93.

26. Rieger K, Loddenkemper C, Maul J, et al. Mucosal $\mathrm{FOXP}^{+}$regulatory $\mathrm{T}$ cells are numerically deficient in acute and chronic GvHD. Blood 2006;107:1717-23.

27. Makita S, Kanai T, Oshima S, et al. CD4+CD25bright $T$ cells in human intestinal lamina propria as regulatory cells. J Immunol 2004;173:3119-30.

28. Yu QT, Saruta M, Avanesyan A, et al. Expression and functional characterization of FOXP3 ${ }^{+} \mathrm{CD} 4+$ regulatory $\mathrm{T}$ cells in ulcerative colitis. Inflamm Bowel Dis 2007;13:191-9.

29. Pasare C, Medzhitov R. Toll pathway-dependent blockade of CD4(+)CD25(+) T cell-mediated suppression by dendritic cells. Science 2003;299:1033-6.

30. Peng GY, Guo Z, Kiniwa Y et al. Toll-like, receptor 8-mediated reversal of $\mathrm{CD} 4(+)$ regulatory $\mathrm{T}$ cell function. Science 2005;309:1380-4.

31. Baecher-Allan C, Viglietta V, Hafler DA. Inhibition of human $\mathrm{CD} 4(+) \mathrm{CD} 25(+$ high) regulatory $\mathrm{T}$ cell function. J Immunol 2002;169:6210-7.

32. Lord JD. Promises and paradoxes of regulatory $\mathrm{T}$ cells in inflammatory bowel disease. World J Gastroenterol 2015;21:11236-45.

33. Dulai PS, Siegel CA. The risk of malignancy associated with the use of biological agents in patients with inflammatory bowel disease. Gastroenterol Clin North Am 2014;43:525-41.

34. Dulai PS, Thompson KD, Blunt HB, et al. Risks of serious infection or lymphoma with anti-tumor necrosis factor therapy for pediatric inflammatory bowel disease: a systematic review. Clin Gastroenterol Hepatol 2014;12:1443-51.

35. Ogawa A, Andoh A, Araki Y, et al. Neutralization of interleukin-17 aggravates dextran sulfate sodium-in- 
duced colitis in mice. Clin Immunol 2004;110:55-62.

36. Zhang Z, Zheng M, Bindas J, et al. Critical role of IL17 receptor signaling in acute TNBS-induced colitis. Inflamm Bowel Dis 2006;12:382-8.

37. Maxwell JR, Zhang Y, Brown WA, et al. Differential Roles for Interleukin-23 and Interleukin-17 in Intestinal Immunoregulation. Immunity 2015;43:739-50.

38. Lee JS, Tato CM, Joyce-Shaikh B, et al. Interleukin-23-Independent IL-17 Production Regulates Intestinal Epithelial Permeability. Immunity 2015;43: 727-38.

39. Abraham C, Dulai PS, Vermeire S, et al. Lessons learned from trials targeting cytokine pathways in patients with inflammatory bowel diseases. Gastroenterology 2017;152:374-388.

40. Elson CO, Cong Y, Weaver CT, et al. Monoclonal anti-interleukin 23 reverses active colitis in a $\mathrm{T}$ cell-mediated model in mice. Gastroenterology 2007;132:2359-70.

41. Yen D, Cheung J, Scheerens H, et al. IL-23 is essential for $\mathrm{T}$ cell-mediated colitis and promotes inflammation via IL-17 and IL-6. J Clin Invest 2006;116:1310-6.

42. Kullberg MC, Jankovic D, Feng CG, et al. IL-23 plays a key role in Helicobacter hepaticus-induced $\mathrm{T}$ cell-dependent colitis. J Exp Med 2006;203:2485-94.

43. Desreumaux P, Foussat A, Allez M, et al. Safety and efficacy of antigen-specific regulatory T-cell therapy for patients with refractory Crohn's disease. Gastroenterology 2012;143:1207-17. 